\title{
A Note on Sources
}

In the following tables and text, population totals and characteristics are from the U.S. Census Bureau unless otherwise indicated. Estimates for the 1960 Hispanic population are from Alice Eichholz, ed., Red Book: American State, County, and Town Sources (Provo, UT: Ancestry, 2004).

Election-related data comes from a variety of sources. Voter registration totals are from Texas Almanac, 1961-1962 (Dallas: A. H. Belo Company, 1961) for 1960; Texas Almanac, 1992-93 (Dallas: Dallas Morning News, 1991) for 1990; and from the Elections Division of the Texas Secretary of State for 2010.

County-level returns for presidential (1848-1988), U.S. senatorial (1912-1990), and gubernatorial (1845-1990) elections can be found in Mike Kingston, Sam Attlesey, and Mary G. Crawford, eds., The Texas Almanac's Political History of Texas (Austin: Eakin Press, 1992). Election returns for these offices from 1992 to the present were obtained from the Elections Division of the Texas Secretary of State.

The partisan affiliation of members of the Texas legislature was obtained from the Legislative Reference Library of Texas. Information on the partisan affiliation of county elective officials is not readily available. While the Texas State Directory (Austin: Texas State Directory, various years) has been published since 1935 as a reference guide and currently lists the party affiliation of most state elective officials, it does not indicate party for county officeholders. A number of documents prepared by the Republican Party of Texas and in author's possession list the names of Republican county elected officials for various years. Data on party affiliation for county judges, commissioners, and sheriffs as of 2013 was obtained by the author directly from county sources.

While some earlier Republican primary data is available from the Texas 
State Archives, returns for several years were among the author's personal papers or were included in the John G. Tower Papers. Both Republican and Democratic primary returns for state offices beginning with 1992 can be found at the Elections Division of the Texas Secretary of State. Democratic primary data for selected offices from 1908 to 1990 is included in Kingston, Attlesey, and Crawford, eds., The Texas Almanac's Political History of Texas.

Public opinion survey data on party identification was obtained from several sources, including the John G. Tower Papers, the Texas Poll Report, and the author's personal files.

Some of the data on straight-ticket voting for 1988 to 2010 is available in "Studies of Political Statistics: Straight Ticket Voting in Texas, 1998-2012," Report no. 8, Center for Public Policy and Political Studies, Austin Community College, Austin, Texas, December 2012. This data was augmented by information collected by the author directly from the 112 counties surveyed. 
Red State 
THIS PAGE INTENTIONALLY LEFT BLANK 